\title{
Men's Violence, Men's Parenting and Gender Politics in Sweden
}

\author{
Maria Eriksson
}

Originally published in NORA, Nordic Journal of Women's Studies 10(1), 2002.

Reproduced with permission (www.tandf.no/nora).

\begin{abstract}
The aim of the article is to open up for further discussion and empirical research the relation of men's violence to men as parents. Drawing upon previous research on men's violence against women, it is suggested that a man's relationship with his partner and relationships with his children can be conceptualized as arenas linked to an overall process of gender constitution. Also discussed is how Swedish policy creates a context for men's identity work and practices as parents that is enabling with regard to men's access to children, but restraining with regard to action against men's violence post-separation/divorce.
\end{abstract}

The political scientist Maud Eduards has claimed that in politics, men tend be invisible as gender (Eduards 1998). Paraphrasing Eduards, I would argue that fathers tend to be invisible as gender, especially with regard to the phenomenon of violence in close relationships. In the research on men generally, there has been a significant lack of focus on the violence of fathers as well as men in other caring positions (Folkesson 2000; Hautanen forthcoming; Hearn 1990, 1999; Pringle 1998). The main concern in most Nordic studies on fatherhood and fathers has been gender equality and more recent Swedish studies on fatherhood and the practices of fathers have typically focused on "normal" fathers or "new" fathers (Højgaard 1997; Hagström 1999; Kearney et al. 2000; Plantin 2001). The issue of violence has not been a main concern. Furthermore, there is a lack of focus on men as fathers in the literature on men's violence against women (Peled 2000).

In this article I focus on men as parents and as gender, especially men who are violent to women. I suggest a framework for conceptualizing parenting by men who are violent to women, and thereby open up for further discussion and empirical research that relates men's violence to men as parents. The aim is also to discuss men's identity work and men's gendered and gendering practices as parents in relation to the policy context of Sweden today, especially policy on child custody, residence and contact.

I start by drawing upon previous research on men's violence against women, to outline the conceptual framework. Thereafter, recent developments in law and policy in Sweden are in focus, including the "post-separation/divorce nuclear family" which is the outcome of the development in recent decades. Finally, I discuss parenting by men who are violent towards women in the context of separation and divorce.

\section{DOING GENDER}

My point of departure is that gender is "... a cultural dynamic formed, recreated and renewed in interaction as an inseparable part of the reproduction of the social order" (Højgaard 1997, 247). However, it is an empirical question, for example, as to how parent-child relationships are gendered and gendering. To discuss processes of gender construction, I primarily draw upon the tradition of "doing gender" perspectives, where 
(inter)action and processes of construction of meaning are in focus. ${ }^{1}$

I seek to avoid essentializing the meaning of gender and at the same time to recognize that, empirically, gender constructs are often stable phenomena, which are difficult to change (Eriksson and Eriksson, 2002; Lundgren 1995). I perceive gender as constructed and changed, although always in relation to a context that can be more or less enabling or restraining (Giddens 1984). Here it is primarily Swedish family policy and public debates that are in focus as parts of the context for men's identity work and practices as parents.

Even if constructions of parenthood are changing today, mothers and fathers are still perceived as different and complementary, at least to a certain degree. Mothers and fathers are differentiated following the logic of opposites in our culture, and it can be argued that parenthood assumes different significance in the lives of women and men, respectively (Højgaard 1997; cf. Bekkengen 1999; Hagström 1999; Kugelberg 1999).

\section{MEN'S VIOLENCE AND CHILDREN'S WELLBEING}

The most recent Nordic surveys on men's violence against women indicate that this is a problem in a considerable proportion of close (heterosexual) relationships. ${ }^{2}$ For example, according to the Finnish study, $22 \%$ of all married and cohabiting women have been victims of physical or sexual violence or threats of violence by their present partner ( $9 \%$ in the course of the past year) (Heiskanen and Piispa 1998). In the Swedish study the comparable figure is $11 \%$ (Lundgren et al. 2001). Furthermore, according to the latter study, $35 \%$ of separated or divorced women have been exposed to physical or sexual violence or threats of violence by a former partner. ${ }^{3}$

We can gain important knowledge about men who are parents and are violent towards women by looking at what is known about children. Since the 1980s, research from a range of countries and evidence from refuges has indicated that violence against women is an issue of direct concern for children (Eriksson and Hester. 2001). Almost all children in these families are subjected to the emotional cruelty of being aware of and/or witnessing violence against their mother. About half of the children are themselves subjected to physical violence and as much as a third (mainly girls) might be subjected to sexual violence (Christensen 1990; Hester et al. 2000; Jaffe et al. 1990; Peled 2000; SOU 1995:60; Weinehall 1997).

The few existing international studies on violent men as fathers suggest that men who are violent to women tend to construct fatherhood in terms of "rights" to children and that they may be more concerned with maintaining control over their children than with nurturing them (Arendell 1992; McMahon and Pence 1995; quoted in Peled 2000). "They were found to be far more likely to fight for custody or not pay child or spousal support than were non-abusive men" (Peled 2000, 29). A more recent study from the UK indicates that men's violence against children post-divorce may be linked specifically to childcare activities (e.g. mealtimes or putting children to bed) (Harne 1999).

In the absence of equivalent Nordic studies, I accept these research findings as relevant to the discussion of parenting by men who are violent to women in a Nordic context as well. Furthermore, I want to suggest that the by now well-documented overlap between men's violence to women and physical, sexual and psychological violence against the children in the family can be interpreted as depending upon something more than "inadequate parenting skills".

\section{FATHERS DOING GENDER THROUGH VIOLENCE TO CHILDREN}

The existing research on men's violence against adult women can be a starting-point for outlining a framework for conceptualizing parenting by men who are violent towards women, a framework which of course has to be evaluated and developed further through empirical research. In Nordic research on men's violence against women, the sociologist Eva Lundgren made use of a doing 
gender perspective early on (e.g. Lundgren 1989). To capture the ongoing identity work and gendered and gendering practices, Lundgren developed the concept gender constitution process (cf. Connell 1987). She suggests that a partner relationship, including violence in that relationship, can be interpreted as an arena for doing gender (cf. Dobash and Dobash 1998; Hearn 1998). ${ }^{4} \mathrm{Or}$, as she puts it: a man "becomes a man" through violence to his (female) partner. The exercise of power can be interpreted as integral to the man's way of doing masculinity: he is doing gender as asymmetrical power relations.

Both internationally and in a Nordic context, a number of scholars have pointed out that men do gender also through their practices and identity work as fathers (e.g. Björnberg et al. 1994; Hagström 1999; Højgaard 1997; Kearney et al. 2000; Marsiglio 1995; Plantin 2001). If a man develops violent behaviour towards his partner, what are the implications for his practices as parent? I suggest that a man's relationship with his partner and his relationships with his children can be conceptualized as parts of the same gender project, as arenas that might be linked to an overall process of gender constitution. However, it is an empirical question as to how and to what degree the arenas are linked.

There are examples in the existing research suggesting that a man who is violent towards women can also do masculinity as domination in relation to his children. In a Swedish study of teenagers growing up in the proximity of violence, a boy says about his father:

If you show that you have opinions of your own...that's when everything goes wrong. So if I'm just going along with it, it's okay, but opinions of your own, that's not possible. But he is really fun. But he is domineering, he can be really bloody crazy, actually. (Weinehall 1997, 150; author's translation)

This quotation can be interpreted as suggesting that the father wants his son to confirm that it is the father's opinions that are the valid ones. To be an adult man and father equals knowing and defining reality. There seems to be very little room for the boy to have a will of his own.

Another example comes from an interview with a man who has been violent towards his wife for many years (Lundgren 1992). He considers it to be his task to shape her into a "real" woman: a woman who is not "contrary", but is "a pleasure" for the man. This man, who lives in a charismatic Christian context, says about his daughter:

My daughter, she is a lily. I will protect her and support her. She is my lily. I will shape her so that she will please the Lord. She will be soft, warm to the Lord. (Lundgren 1992, 60; author's translation.)

One possible interpretation is that the man can use not just the relationship with his partner, but also the relationship with the daughter, to become the man and father he wants to be. He is perhaps unusually explicit about what he considers to be his task: to be the one that shapes a woman and a daughter. Here the father-daughter relationship can be interpreted as an arena for doing masculinity as domination (cf. Brantsæter 2001).

\section{DAUGHTERS AND SONS}

Both boys and girls can share the experience of being at the receiving end of oppressive father-child relations. However, the existing research and knowledge from practice suggests that a man might do gender differently depending upon whether it is a father-son relationship or a father-daughter relationship. Men might, for example, relate to their daughters as "replacement spouses", and bond with their sons around a common "maleness" (Brantsæter 2001; Morris 1999/2000).

Here it can be added that other sections of the interview with the father quoted above make it clear that the man's shaping of his daughter includes abusing her sexually. The sexual violence to the 
daughter can, in other words, be conceptualized as an arena for his identity work as man and father. ${ }^{5}$

From the children's point of view, their father's way of doing gender might put them at risk of harm and of becoming victims of crime. Furthermore, if the father is doing gender through violence in relation to themselves, they also learn something very concrete about what it means to be a girl or a boy, a woman or a man (Lundgren 1994; Weinehall 1997).

\section{SWEDISH FAMILY POLICY}

Swedish family policy presupposes shared parenting and a high degree of parental cooperation post-separation/divorce. The policy is based primarily upon the notion of the child's right to a close contact with both (biological) parents and the aim of many Swedish welfare reforms has been to enable both parents to take part in the everyday care of children (Bergman and Hobson 2002; Hagström 1999; Sainsbury 1999; Schiratzki 1997) ${ }^{6}$

Changes since the late 1970s to the family law - the Code on Parenthood (Föräldrabalken) have aimed to reduce conflict between couples and to encourage agreements over residence, custody and contact (Nordborg 1997; Prop. 1997/98:7; Schiratzki 1997; SOU 1995:79). Mothers and fathers are today expected to be able to share custody and parenting jointly, preferably without interference from the state. Joint custody is thought to guarantee stability in the child's contact with both parents in a way that resembles the (heterosexual) nuclear family as much as possible, even though the parents do not live together (any longer) (Schiratzki 1997, 55). The outcome of the development of the law and policy on residence, custody and contact is a new private sphere - a "post-separation/divorce nuclear family" (Eriksson and Hester 2001; cf. Kurki-Suonio 2000; Smart 1999; Simpson 1998). The question is what this might mean for the everyday life of mothers, fathers and children (cf. Neale and Smart 1997).

\section{MEN'S VIOLENCE AND FAMILY LAW}

There is today an increasing recognition in Sweden of men's violence against women as a social problem (Eriksson and Hester 2001; Lundberg 2001). Furthermore, in the 1990s the issue has been the objective of law reforms, and Swedish legislation today acknowledges violence in heterosexual relationships as gendered, as primarily violence by men against women (Prop. 1997/98:55; SOU 1995:60).

However, as I have argued elsewhere (together with Marianne Hester), despite the growing recognition of the gendered features of violence in heterosexual relationships, fathers are still to an overwhelmingly large extent constructed as essentially non-violent (Eriksson and Hester 2001). Here it can be added that Swedish policy on violence against women has tended to focus on protection and support to women and to some extent to children. Violent men are seldom in focus as parents and they can thereby avoid being held responsible for the well-being of their children (Eriksson 2001; Peled 2000). In sum, policy discussions in Sweden tend to present fathers as either good for children, or absent (and therefore not so good for children): but not as violent. ${ }^{\text {? }}$

In the law it is clearly stated that all decisions concerning custody, contact or residence should be based upon the best interests of the child (Code on Parenthood 6, ch. 2aß). Several authors have pointed out that the concept of the best interests of the child is an open concept and the content might differ depending on the social, historical and cultural context (Kurki-Suonio 2000; Schiratzki 1997; Simpson 1998). The hegemonic interpretation in official Sweden today is that it is in the best interests of the child that the parents share custody and that the child has unsupervised face-to-face contact with the non-residential parent (typically the father). Joint custody is considered to be so important that following the most recent changes to the law (1998), courts can even award joint custody against the will of one parent (which was not possible before). 
In the preparatory work to the law, it is mentioned that there are cases where the general principles of joint custody and unsupervised face-to-face contact do not apply, but very little attention has been given to these exceptions. The issue of men's violence has to only a very limited extent been discussed in relation to the (continued) parental cooperation and the wellbeing of children post-divorce/separation (Eriksson and Hester 2001).

Lack of clarity, in family law and the preparatory work, on the issue of men's violence seems to give the legal practice a central role for shaping the policy in this field. The development of legal practice needs to be investigated further, but some legal cases suggest that the presumption in practice is that a father who has been violent towards women is a good-enough custodian (and contact parent) until proven otherwise (Eriksson 2001; SVT 2001; Wallin 2000). He is presumed to be safe and respectful enough for joint custody or unsupervised contact to be considered as without risk for the child and the child's mother despite his previous behaviour. The burden of proof is placed on the abused woman if she does not want joint custody or unsupervised contact (cf. Schiratzki 1997). ${ }^{8}$

\section{MEN'S VIOLENCE AND SEPARATION/DIVORCE}

A crucial question for policy and practice is of course whether and how a father's way of doing gender might change with a separation or divorce. Research shows that many men continue to be violent (Hester and Radford 1996; Hester et al. 2000; Lundgren et al. 2001). Against the backdrop of the conceptual framework outlined above, this is not surprising. If violence towards women and/or children is an integral part of a man's way of doing gender, it is to be expected that some men will continue to be violent post-separation/divorce. A man does not stop doing gender because he is going through a separation/ divorce. ${ }^{9}$

When a man has a history of being violent towards his partner, we cannot take it for granted that the father-child relationship will develop in a way that is in the best interests of the child post-separation/divorce. With the woman no longer available to him, the relationship with a child - and violence against the child - might be the only arena for doing masculinity as dominance that is accessible to him. There might, in other words, be reasons for expecting some children to be at increased risk of abuse post-separation/divorce, even if the father has not been violent to the child prior to the separation/divorce (cf. Citron 2001).

\section{GENDERED PARENTS AND SEPARATION/DIVORCE}

Drawing upon the work of Carol Smart (1999), I want to problematize gender-neutral notions of parents in the context of separation and divorce (cf. Simpson 1998; Ribbens McCarthy et al. 2000). Smart is highly critical of the thinking behind the English Children Act (1989), which bears many similarities to the ideas behind the Swedish Code on Parenthood. She argues that it is presumed that a distinction can be made between the adult-adult relationship and the adult-child relationship within a marriage or cohabitation (Smart 1999, 101). While a separation/divorce is thought to end the relationship between the adult partners, the relationship between adults and children are presumed to go on almost as if nothing has happened. Two sets of relationships are supposed to exist independently of one another. ${ }^{10}$

Smart argues that we need to have a much more complex picture of how relationships, which are formed during a marriage or cohabitation, can be reshaped or transformed after separation or divorce. Parents do not only relate to one another as partners, but also as parents: "A mother's relationship to a father is not the same as a wife's relationship to a husband" (Smart 1999, 102). According to Smart, it is not uncommon for a (British) father to rely on the mother in order to have a relationship with his children. The mother has to mediate and interpret the children's needs or translate their moods to him, and she is the one taking the overall emotional and practical responsibility for the children. "It is possible to 
argue that fatherhood depends upon motherhood for its satisfactory existence as a relationship (as opposed to as a biological fact)" (Smart 1999, 103).

In "intact" families, this pattern of family relations is often taken for granted. However, with a separation or divorce, the relationships are renegotiated and the implications become visible, according to Smart. "Passive" fatherhood is no longer possible and men may experience a radical change away from a taken-for-granted dominant position in the family (cf. Simpson 1998, $191 \mathrm{ff}$.). Women's greater responsibility for children's emotional and physical needs is often perceived as acceptable or positive as long as (heterosexual) partnership, parenthood and residence coincide. However, a woman's special relationship to the children might be interpreted, for example by the father, as an unfair advantage post-divorce.

If the father has relied on the mother in order to have a relationship with his children, he must change the relationship in order to continue to be a father post-divorce. The question is, how might a new, independent relationship between father and child develop when the man has a history of using violence (cf. the discussion above)? Furthermore, Smart argues that if a post-divorce father will not, or cannot, take on more responsibility for his relationship with his children, the mother might be obliged to remain his "spouse". For, one of her key roles, that of mediating the father's relationship with the children, remains unchanged (Smart 1999, 108). The divorce or separation does not necessarily create a new relation, but can perpetuate old relationships across different households. To be a good mother, a woman might have to remain a "wife" - and in the case of violence, a wife to an abusive husband."

\section{GENDERED PARENTS AND POLICY ON GENDER EQUALITY}

Despite the different cultural contexts, I would argue that there are parallels between Sweden and the UK and that the everyday pattern of organizing gender/family relations referred to above can also be found in Sweden, at least to some degree. However, what does differ is the policy context. According to the ideology of gender equality, this pattern of gender/family relations is not acceptable and the Swedish state has created a number of policy measures to achieve a gender equal sharing of childcare responsibilities (Bergman and Hobson 2002; Højgaard 1997; Magnusson 2000).

As long as the partner relationship is ongoing, the state has limited possibilities to influence the negotiations between the parents regarding the care of children (cf. Bergman and Hobson 2002). However, in the context of separation and conflicts concerning custody, residence or contact, mothers or fathers can use legal and policy measures to support their claims (on the child's behalf). In this sense, the postseparation/divorce family is more open to state intervention, but only as far as there exist legal or policy measures that the parties can use. A Swedish father can, for example, find support for his claims to custody or contact in public discourses on gender equality (cf. Magnusson 2000). Furthermore, he can activate the legal framework to support his interests and to gain access to his children. In relation to men's violence, the legal measures a mother can use to protect herself and the children post-separation/ divorce seem to be more limited, if not in principle at least in practice (cf. the discussion above). The post-separation/divorce nuclear family seems to be more private with regard to interventions to counteract men's abuse of power than with regard to men's ongoing contact with their children.

\section{WHAT ABOUT THE FUTURE?}

Today we see changes in the social construction of fatherhood in Sweden and it can be argued that being an involved and active father is becoming increasingly central to hegemonic constructions of masculinity (Bergman and Hobson 2002; Connell 1987). There are reasons to expect increased social pressures on fathers to have close contact with their children. The implication is also, of course, that a violent father will have to have contact with his children to be able to create an 
acceptable self-image and to obtain social recognition. The question is, what this development might mean for conflicts concerning custody and contact, as well as postseparation/divorce parenting by men who are violent towards women.

Swedish family policy creates a context for men's identity work and practices as fathers that is very enabling with regard to access to children. Fathers - including those who are violent towards women - can make use of law and the ideology of gender equality when trying to get access to (gendered and gendering) care of children. The context is on the other hand restraining in relation to the work against men's violence and the post-separation/divorce protection of children and mothers. Mothers - including those who have been victims of violence - can find themselves in a Catch 22 (no-win) situation where they, as "good mother custodians", are expected to facilitate the children's contact with the father, and at the same time protect the children from harm. There are presently limits to what extent legal measures can be used for protection. Furthermore, there are no widely held public discourses on parenting by men who are violent towards women that can be used to make fathers accountable for violence in a post-separation/divorce context, or to induce fathers who are violent towards women to change. So, there are not just research-based reasons but also gender and child political reasons for filling the gaps in current research.

\section{ENDNOTES}

1. See, e.g., Acker (1990); Dryden (1999); Gherardi (1994); Kessler and McKenna (1978); Lundgren (1995); West and Zimmerman (1987). For a discussion of different doing gender perspectives, see Korvajärvi (1998).

2. These studies do not give us any definite figures on the number of men who are violent towards women, nor the number of fathers who are violent towards women. However, the studies are based upon a representative sample of the population and it can therefore be assumed that a significant proportion of the men concerned are fathers.

3. In Finland, the comparable figure is $50 \%$.

4. For further elaboration, see Lundgren $(1989,1995)$.

5. cf. the respondent "Christian" in Brantsæter (2001, $157 \mathrm{ff}$.). 
6. In other words, the family law is consistent with the welfare state gender regime of an individual earner û carer model (Sainsbury 1999).

7. For example, the exhibition Dear Child. On Men, Children and Gender Equality in Sweden, on tour in Europe during Sweden's presidency of the EU in 2001 (The Swedish Institute 2001). For discourses on child welfare, see for example Jonsson et al. (2001).

8. This presumption can result in destructive outcomes for women and children. A violent father can, for example, under the Code on Parenthood undermine any attempt from the mother to provide the children with counselling dealing with the effects of his violence (Prop. 1998/99:133; SOU2001:72).

9. The assumption that men are "freed" from being violent through the separation readily feeds into victim-blaming perceptions of men's violence against women.

10. In the Swedish context (at least) two different discourses are used in policy discussions. According to the gender-neutral "Custody Conflict Discourse", what happens in the adult relationship can be separated from(a) shared parenting post-separation/divorce and (b) parent-child relationships and children's well-being (see SOU 1995:79). According to the "Violence AgainstWomen Discourse", which is less central to Swedish family policy, violence in the adult relationship is connected to gendered power, (shared) parenting post-separation/divorce as well as to parentûchild relationships and children's well-being (see SOU1995:60).

11. Gudrun Nordborg suggests that fatherhood has replaced marriage as the social institution enabling men to control women (1997).

\section{ACKNOWLEDGEMENTS}

I thank Lena Berg, Emmi Lattu, Jeff Hearn and Keith Pringle for helpful comments and suggestions. I also thank the seminar in gender studies, Department of Sociology, Uppsala University, for comments on a draft of the manuscript. The research project in the Best Interests of Children. Gender, Violence and Parenthood at Divorces and Separations, Department of Sociology, Uppsala University, has received grants from The Crime Victim Compensation and Support Authority.

\section{REFERENCES}

Acker, Joan. 1990. Hierarchies, jobs, bodies: a theory of gendered organizations. Gender and Society, 2, 139-158.

Arendell, Terry. 1992. The social self as gendered: a masculinist discourse of divorce. Symbolic Interaction, 15, 151-181.

Bekkengen, Lisbeth. 1999. Män som"pappor" och kvinnor som"föräldrar" (Men as "daddies" and women as "parents"). Kvinnovetenskaplig tidskrift, 1, 33-48.

Bergman, Helena and Hobson, Babara. 2002. Compulsory fatherhood: the coding of fatherhood in the Swedish welfare state. In Hobson, Barbara (ed): Making men into fathers. Men, masculinities and the social politics offatherhood. Cambridge: Cambridge University Press, $92 u ̂ 124$.

Bjömberg, Ulla, Kollind, Anna-Karin and Nilsson, Ame (eds). 1994. Janus och genus. Omkön och social identitet i familj och samhälle (Gender and social identity in family and society). Brombergs bokförlag.

Brantsæter, Marianne. 2001. Moter med menn domt for seksuelle overgrep mot barn (Encounters with men convicted of sexual abuse against children). Oslo: University of Oslo.

Christensen, Else. 1990. Børnekår. En unders øgelse af omsorgssvigt $\mathrm{i}$ relation til børn og unge $\mathrm{i}$ familier med hustrumishandling (Children's living conditions. An investigation into disregard of care in relation to children and teenagers in families of wife mal-treatment). Nordisk Psykologis monografiserie, 31, 161 û232.

Citron, Christina. 2001. Bryt hemlighetsmakeriet! (Stop the mystery-making!). Socionomen, 4, 39 û 42.

Connell, RobertW, 1987.Gender and power. Society, the person and sexual politics. Cambridge: PolityPress.

Dobash, R. Emerson and Dobash, Russell P. 1998. Rethinking violence against women. London: Sage.

Dryden, Caroline. 1999. Being married. doing gender. A critical analysis of gender relationships in marriage. London: Routledge. 
Eduards, Maud. 1998.Män-finns de? (Men -do they exist?). Kvinnovetenskaplig tidskrift, 3/4, 77-85.

Eriksson, Kristina and Eriksson, Maria. 2002. Kön har ingen betydelse, men könsblandning är bra - "könsgörande" i två professionella sammanhang (Gender is irrelevant, but a gender-mix is g ood - doing gender in two professional contexts). Kvinnovetenskaplig tidskrift, 1, 53-72.

Eriksson, Maria. 2001. Omvå rdnad, boende och umgänge (Custody, residence and contact). In Metell, Barbro (ed.): Barn somser pappa slå (Children who see daddy hit). Stockholm: Förslagshuset Gothia, 104-137.

Eriksson, Maria and Hester, Marianne. 2001. Violent men as good-enough fathers? A look at England and Sweden. Violence A gainst Women, 7, 779-799.

Folkesson, Per. 2000. En kartläggning av nordisk mansforskning(Nordic men's studies: an overview). In Folkesson, Per, Nordberg,Marie and Smirthwaite, Goldina (eds): Hegemoni och mansforskning (Hegemony and men's studies). Karlstad: Karstads University, 67-94.

Gherardi, Silvia. 1994. The gender we think, the gender we do in our everyday organizational lives. Human Relations, 6, 591-610.

Giddens, Anthony. 1984. The constitution of society. Cambridge: Polity Press.

Hagström, Charlotte. 1999. Man blir pappa. Föräldraskap och maskulinitet i förändring (Man/one becomes father. Parenthood and masculinity in change). Lund: Nordic Academic Press.

Harne, Lynne. 1999. Violent fathers and contact. Key note at the conference Face to face. Children, safety and parental contact. London, November 18-19, 1999.

Hautanen, Teija 2002. Fatherhood and violence - an awkward research topic? Janus - Journal of the Finnish Society for Social Policy (forthcoming).

Hearn, Jeff. 1990. "Child abuse" and men's violence. In The violence against children study group: Taking child abuse seriously: contemporary issues in child protection theory and practice. London: Unwin Hyman, 63-85.

Hearn, Jeff. 1998. The violences of men.How men talk about and how agencies respond to men's violence to women. London, Thousand Oaks and New Delhi: Sage.

Hearn, Jeff. 1999. Ageism, violence and abuse. Theoretical and practical perspectives on the links between "child abuse" and "elder abuse". In The violence against children study group: Children, child abuse and child protection: placing children centrally. Chichester: Wiley, 81-96.

Heiskanen, Markku and Piispa, Minna. 1998. Faith, hope, battering. Asurvey ofmen's violence against women in Finland. Helsinki: Statistics Finland.

Hester, Marianne and Radford, Lorraine. 1996. Domestic violence and child contact arrangements in England and Denmark. Bristol: The Policy Press.

Hester,Marianne, Pearson,Chris andHarwin,Nicola. 2000. Making an impact: children and domestic violence. A reader. London: Jessica Kingsley.

Højgaard, Lis. 1997. Working fathers - Caught in the web of the symbolic order of gender. ActaSociologica, 3, 245-262.

Jaffe, Peter G., Wolfe, David A. andWilson, Susan Kaye. 1990. Children of batteredwomen. Newbury Park, London and NewDelhi: Sage.

Jonsson, Jan O., Östberg, Viveca and Palme, Joakim. 2001. Var tredje träffar inte ena föräldern (One in three does not see one parent). Dagens Nyheter, August 21, 2001, A4. 
Keamey, Jeremy,Må nsson, Sven-Axel, Plantin, Lars, Pringle,KeithandQuaid, Sheila. 2000. Fatherhood and masculinities. A comparative study of the ideals and realities of fatherhood and masculinity in Britain and Sweden. Sunderland: University of Sunderland.

Kessler, Suzanne and McKenna, Wendy. 1978. Gender: An ethnomethodological Approach. Chicago: The University of Chicago Press. Korvajärvi, Päivi. 1998. Gendering dynamics in white-collar work organizations. Tampere: University of Tampere.

Kugelberg, Clarissa. 1999. Perceiving motherhood and fatherhood. Swedish working parents with young children. Uppsala: Uppsala University.

Kurki-Suonio, Kirsti. 2000. Joint custody as an interpretation of the best interests of the child in critical and comparative perspective. International Journal of Law, Policy and the Family, 14, 183-205.

Lundberg, Magnus. 2001. Vilja med förhinder. Polisers samtal omkvinnomisshandel (Intention with impediments. Police conversations on violence against women). Stockholm: Brutus Östlings Bokförlag Symposion.

Lundgren, Eva. 1989. Våldets normaliseringsprocess - två parter, två strategier (The normalization process of violence û two parties, two strategies). Kvinnomisshandel (Violence against women). Stockholm: Jämfo-rapport nr 14, 113-140.

Lundgren, Eva. 1992. Gud och alla andra karlar. En bok omkvinnomisshandlare. (God and everyMan? Abook about men who are violent to women). Stockholm: Natur och Kultur.

Lundgren, Eva. 1994. La de små barn komme til meg. Barns erfaringer med seksuelle og rituelle overgrep (Suffer the little children to come unto me. Ritual and sexual abuse). Oslo: Cappelen forlag.

Lundgren, Eva. 1995. Feminist theory and violent empiricism. Aldershot: Avebury.

Lundgren, Eva, Heimer, Gun, Westerstrand, Jenny and Kalliokoski, Ann-Marie. 2001. Slagen Dam. Mäns våld mot kvinnor i jämställda Sverige - en omfå ngsundersökning (Men's violence against women in gender equal Sweden - a national survey). Umeå and Uppsala: The Crime Victim Compensation and Support Authority and Uppsala University.

Magnusson, Eva. 2000. Party-political rhetoric on gender equality in Sweden: The uses of uniformity and heterogenity. NORA, $2,78-92$.

Marsiglio, William. (ed.) 1995. Fatherhood. Contemporary theory, research and social policy. Thousand Oaks, London and NewDelhi: Sage.

McMahon, Martha and Pence, Ellen. 1995. Doing more harm than good? Some cautions on visitation centers. In Peled, Einat, Jaffe, Peter G. and Edleson, Jeffrey. L. (eds): Ending the cycle of violence: community responses to children of battered women. Newbury Park, CA: Sage, 186-206.

Morris, Anne. 1999/2000. Adding insult to injury. Trouble \& Strife, Winter 1999/2000, 30-35.

Neale, Bren and Smart, Carol. 1997. Experiments with parenthood? Sociology, 2, 201-219.

Nordborg, Gudrun. 1997. Omjuridikens kön (The gender of law). In Nordborg, Gudrun (ed.): Makt and kön. Tretton bidrag till feministisk kunskap (Gender and power. Thirteen contributions to feminist knowledge). Stockholm: Symposion, 171-198.

Peled, Einat. 2000. Parenting by men who abuse women: issues and dilemmas. British Journal of Social Work, 30, 25-36.

Plantin, Lars. 2001. Män, familjeliv \&föräldraskap (Men, family life \&parenthood). Umeå : Boré bokförlag.

Pringle, Keith. 1998. Men and child care: policy and practice. In Popay, Jennie, Hearn, Jeff and Edwards, Jeanette (eds):Men, gender divisions and welfare. London: Routledge, 312-336.

Prop. 1997/98:55. Kvinnofrid (Women's peace). 


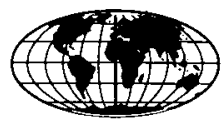

Prop. 1997/98:7. Vå rdnad, boende, umgänge (Custody, residence and access).

Prop. 1998/99:133. Särskild företrädare för barn (Special representative for children).

Ribbens McCarthy, Jane, Edwards, Rosalind and Gillies, Val. 2000. Moral tales of the child and the adult: narratives of contemporary family lives under changing circumstances. Sociology, 4, 785-803.

Sainsbury, Diane. 1999. Gender and socialdemocratic welfare states. In Sainsbury, Diane (ed.): Gender and welfare state regimes. Oxford: Oxford University Press, 75-114.

Schiratzki, Johanna. 1997. Vårdnad och vårdnadstvister (Custody and custody disputes). Stockholm: Nordstedts.

Simpson, Bob. 1998. Changing families. An ethnographic approach to divorce and separation. Oxford and NewYork: Berg.

Smart, Carol. 1999. The "new" parenthood: fathers and mothers after divorce. In Silva, Elisabeth B. and Smart, Carol (eds): TheNEWFamily? London: Sage, 101-114.

SOU1995:60. Kvinnofrid (Women's peace).

SOU1995:79. Vå rdnad, boende, umgänge (Custody, residence and access).

SOU2001:72. Barnmisshandel - Att förebygga och å tgärda (Child abuse - prevention and intervention).

SVT 2001. Uppdrag granskning (Mission scrutiny). Sveriges television (Swedish television), December 11, 2001.

The Swedish Institute. 2001. Dear Child - on men, children and gender equality in Sweden. Stockholm: The Swedish Institute.

Wallin, Urika. 2000. De nya vå rdnadsreglerna och praxis (The new custody legislation and praxis). Stockholm: Stockholms University.

Weinehall, Katarina. 1997. Att växa upp $i$ vå ldets närhet. Ungdomars berättelser omvå ld $i$ hemmet (Growing up in the proximity of violence. Teenagers' stories of violence in the home). Umeå : Umeå University.

West, Candance and Zimmerman, Don. 1987. Doing gender. Gender and Society, 2, 125-151. 